\title{
Influence of priming on Eucalyptus spp seeds' tolerance to salt stress ${ }^{1}$
}

\author{
Anderson Cleiton José2*, Natália Cristina Nogueira Silva², \\ José Marcio Rocha Faria ${ }^{2}$, Wilson Vicente Souza Pereira ${ }^{2}$
}

\begin{abstract}
The objective of this experiment was to evaluate the effect of priming on the germination of Eucalyptus urophylla and of hybrid E. urophylla $\times E$. grandis seeds under salt stress. Two osmotic potentials ( -1.0 and $-1.5 \mathrm{MPa})$ were tested, using PEG 6000 for 1 and 3 days. After priming, seeds were germinated under salt stress in a $\mathrm{NaCl}$ solution at 0.0 (control), $-0.5,-0.75$ and $-1.0 \mathrm{MPa}$ potentials, at $25^{\circ} \mathrm{C}$. Seed germination and germination speed index decreased as the water potential of the germination medium decreased. However, E. urophylla was more tolerant to salt stress; it showed a higher germination percentage under all tested potentials, when compared to the hybrid. The osmotic conditioning at $-1.0 \mathrm{MPa}$ for three days was more effective when E. urophylla $x$ E. grandis was germinated in a salt solution at $-1.0 \mathrm{MPa}$, indicating that this treatment was more effective in inducing tolerance to salt stress.
\end{abstract}

Index terms: Eucalyptus urophylla, E. grandis $x$ E. urophylla, abiotic stress, physiological conditioning.

\section{Influência do condicionamento osmótico na tolerância ao estresse salino em sementes de Eucalyptus spp}

\begin{abstract}
RESUMO - Este trabalho teve-se como objetivo avaliar o efeito do condicionamento osmótico na germinação de sementes de Eucalyptus urophylla e do híbrido de E. grandis $x$ E. urophylla em condições de estresse salino. Foram testados dois potenciais de condicionamento induzidos por PEG 6000 (-1,0 e -1,5 MPa) em dois períodos ( 1 e 3 dias). Após o condicionamento osmótico, as sementes foram colocadas para germinar sob estresse salino em solução de $\mathrm{NaCl}$ nos potenciais 0,0 (controle) $-0,5,-0,75$ e $-1,0$ $\mathrm{MPa}$ a $25^{\circ} \mathrm{C}$. Os parâmetros avaliados foram a germinação e o índice de velocidade de germinação (IVG). Houve diminuição da germinação e do IVG à medida que o potencial hídrico do meio germinativo tornou-se mais negativo, tanto para E. urophylla quanto para o híbrido, entretanto, o E. urophylla foi mais tolerante ao estresse salino, em comparação ao híbrido, apresentando maior germinação em todos os potenciais hídricos testados. O osmocondicionamento no potencial de -1,0 MPa por três dias foi o mais indicado tanto para $E$. urophylla quanto para E. urophylla $x$ E. grandis, quando submetidos à germinação em solução salina a -1,0 MPa, demonstrando que esse tratamento foi eficiente em favorecer a tolerância ao estresse salino.
\end{abstract}

Termos para indexação: Eucalyptus urophylla, E. grandis $x$ E. urophylla, estresse abiótico, condicionamento fisiológico.

\section{Introduction}

Abiotic stress, depending on its intensity, may severely limit the growth and development of plants (Kosová et al., 2011; Harfouche et al., 2014); salinity and water deficit are the main factors affecting the productivity of cultures around the world, especially in arid and semi-arid regions (Jisha et al., 2013; Gholami et al., 2015). One of the methods used to determine the tolerance of a plant is evaluating the germination capacity of its seeds under stress (Larcher, 2000).

In the germination medium, salinity not only acts by restricting seed imbibition and causing water stress, but it also causes toxicity, due to $\mathrm{Na}^{+}$and $\mathrm{Cl}^{-}$ions. It creates an ionic unbalance in the cell cytoplasm, which may lead to the formation of reactive oxygen species (ROS); they cause cell membrane lipid peroxidation, damages to the DNA, protein denaturing, carbohydrate oxidation and decrease of the enzymatic activity (Shabala and Munns, 2012).

Physiological conditioning is a widely used technique in studies to induce seed tolerance to various stresses, among which the saline one. It consists in a pre-germination treatment involving the limitation of the imbibition period

${ }^{1}$ Submitted on 06/08/2016. Accepted for publication on 09/13/2016.

${ }^{2}$ Departamento de Ciências Florestais, Universidade Federal de Lavras, Caixa Postal 3037, 37200-000 - Lavras, MG, Brasil.

*Corresponding author $<$ acjose@def.ufla.br $>$

Journal of Seed Science, v.38, n.4, p.329-334, 2016 
or of the water available to seeds; it allows activating seed metabolism without enabling the radicle protrusion or the loss of desiccation tolerance (Ibrahim, 2015).

Osmoconditioning carried out with polyethylene glycol (PEG) is the most used technique among the ones for seed physiological conditioning, since this inorganic compound reduces the osmotic potential of the solution and with this, it performs a controlled hydration without causing toxicity (Taylor et al., 1998). This controlled imbibition may induce mechanisms of protection and repair in seeds, resulting in a possible acclimatization that would allow seeds to tolerate a future stress (Kubala et al., 2015).

Many studies about water stress signaling also use salt stress, since plant responses to droughts and salinity are intimately related and mechanisms overlap, suggesting that both stresses are perceived by cells as an event of water deprivation (Jisha et al., 2013). Thus, this mechanism that allows plants to acclimate to different stresses after being exposed to a specific stress is called cross-tolerance (Pastori and Foyer, 2002).

The objective of this research was to evaluate the effect of $\mathrm{NaCl}$ saline solutions on the germination of $E$. urophylla and hybrid E. urophylla x E. grandis seeds; it also aimed at evaluating cross-tolerance effects induced by osmoconditioning on the germination of seeds under salt stress conditions.

\section{Material and Methods}

This work was carried out in the Forest Seed Laboratory from the Forestry Sciences Department of the Federal University of Lavras. Seeds from a seed orchard were acquired from the Institute for Research and Forestry Studies - IPEF, belonging to the species Eucalyptus urophylla (lot PI0077N01) and E. grandis x E. urophylla hybrid (lot AN0289N01). Seeds were processed in an air blower, stored in plastic containers and placed in a cool chamber $\left(5 \pm 2{ }^{\circ} \mathrm{C}\right.$ and $35 \pm 5 \%$ Relative Humidity) until use.

In order to perform the osmotic conditioning, seeds were placed in Falcon ${ }^{\circledR}$ tubes containing a polyethylene glycol solution (PEG 6000) at -1.0 and $-1.5 \mathrm{MPa}$ potentials, and kept in a BOD type incubator at the temperature of $20^{\circ} \mathrm{C}$, in the dark. The preparation of PEG 6000 solution was based on Sun calculations and recommendations (2002). In order to maintain the oxygenation of solutions, tubes were perforated on the lid and placed in a Multifunctional Mixer (Biomixer ${ }^{\circledR}$ ) rotary shaker, MR-II model.

Osmotic conditioning lasted 1 or 3 days. After the treatment, seeds were quickly washed in running water and placed to dry in a climatized room $\left(20{ }^{\circ} \mathrm{C}\right.$ and $50 \% \mathrm{RH}$ approximately) for 24 hours, enough time to guarantee the return to the initial humidity before conditioning.

After osmotic conditioning and drying, seeds were placed to germinate under $\mathrm{NaCl}$ induced salt stress, at 0.0 (control sample), $-0.5,-0.75$, and $-1.0 \mathrm{MPa}$. The test was conducted with Petri dishes on two germination paper sheets, in BOD type germinators, at the temperature of $25^{\circ} \mathrm{C}$ and under continuous light. The saline solution used to moisten the germination substrate was changed on the third, seventh and eleventh day, to maintain osmotic potentials. Germination was evaluated daily for 15 days, in order to determine germination speed index (GSI) and final germination percentage. As a control sample treatment, seeds were placed to germinate under the same saline conditions without any previous treatment.

The experiment was conducted in completely randomized design, using four replications of 25 seeds in the $(2 \times 2 \times 4)+4$ factorial scheme for each species, constituted by two osmoconditioning potentials $(-1.0$ or $-1.5 \mathrm{MPa})$, two conditioning periods ( 1 or 3 days), four $\mathrm{NaCl}$ induced germination potentials $(0.0,-0.5,-0.75$, and $-1.0 \mathrm{MPa})$ and four additional factors (control sample treatments).

Statistical analysis consisted in an analysis of variance (ANOVA) per species, in order to evaluate the existence of interactions among factors involved in conditioning (conditioning potentials, duration and germination potentials), followed by Scott-Knott test at 5\% significance. The comparison of additional factor averages with their respective treatments was carried out by an ANOVA followed by Dunnett's test.

\section{Results and Discussion}

Seeds from two studied eucalyptus species had a better germination performance when placed in a water-dampened substrate, that is, with no salt stress (Figure 1); the average germination percentage was $100 \%$ (E. urophylla) and $97 \%$ (E. urophylla $\mathrm{x}$ E. grandis). Under salt stress, germination continuously decreases, reaching $39 \%$ and $13 \%$ at $-1.0 \mathrm{MPa}$ for E. urophylla and E. urophylla x E. grandis, respectively. For E. urophylla, it was possible to observe a tendency to maintain a higher final germination percentage, up to the potential of $-0.75 \mathrm{MPa}$ in saline solutions, where germination is $90 \%$. For the hybrid, this germination solution potential causes a marked drop in the germination final percentage, going from $77 \%$ at $-0.5 \mathrm{MPa}$ to $35 \%$ at $-0.75 \mathrm{MPa}$.

Martins et al. (2014) evaluated the effects of water stress, induced by polyethylene glycol and $\mathrm{NaCl}$, in the germination of seeds from five eucalyptus species, among 
which E. grandis and E. urophylla, and verified that the -0.8 $\mathrm{MPa}$ potential already inhibits germination in practically all species, reducing germination to null or close to zero values, both in water and salt stress.

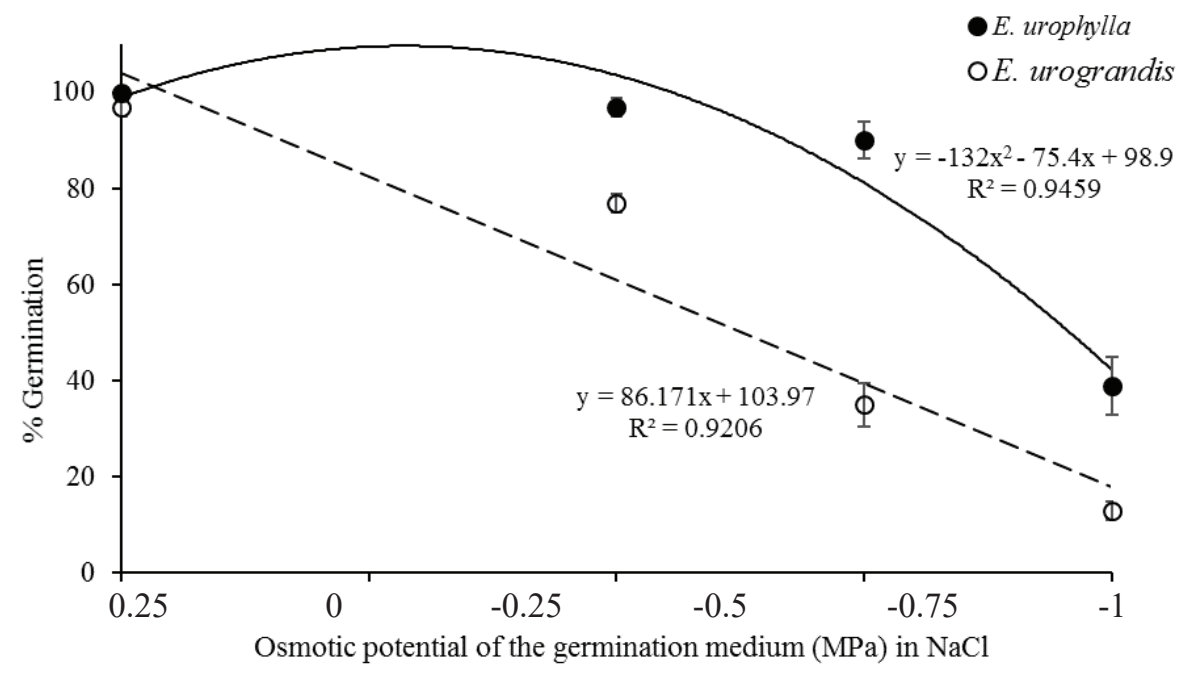

Figure 1. Final germination percentage of Eucalyptus urophylla and E. urophylla $x$ E. grandis seeds, with no priming, submitted to different germination saline potentials. Bars in each point represent the standard deviation.

Feikema and Baker (2011), when studying the growth of three eucalyptus tree species irrigated with saline solution, verified that $E$. grandis is only proper for low salinity soils, since it presented high mortality rate and low volume increment along the years, when submitted to high salinity soils. Similar results were found by Dunn et al. (1994) who, when studying 12 Australian species among the Eucalyptus, Casuarina, Melaleuca and Tipuana genera, in places with different levels of soil salinity, also concluded that E. grandis is moderately tolerant to soil salinity.

Interspecies genetic variations for salt tolerance have been related for the Eucalyptus genus (Niknam and Mccomb, 2000), demonstrating that more studies are needed to exploit the tolerance potential of its species, since many genes are involved in tolerance to salinity (Ashraf, 2004; Su et al., 2011).

For E. urophylla, the interaction between factors (conditioning $\mathrm{x}$ time $\mathrm{x}$ stress) and additional factors was significant on germination, as well as the interaction among conditioning potentials, duration and stress levels.

As it is possible to observe, some conditioning treatments were not efficient, since the final germination percentage of seeds that did not undergo any conditioning treatment remained high, even at a germination saline potential of -0.75 $\operatorname{MPa}(90 \%)$ (Figure 2C).

The germination of E. urophylla drastically decreased only when seeds were placed under -1.0 MPa salt stress. In this case, germination was reduced from $90 \%$ at $-0.75 \mathrm{MPa}$ to $39 \%$ at $-1.0 \mathrm{MPa}$ (Figure 1). Osmotic conditioning at -1.0 $\mathrm{MPa}$ for three days in PEG was enough to raise germination under this salt stress to $66 \%$, being statistically different from the control sample (Figure 2D). Seeds conditioned in PEG at $-1.5 \mathrm{MPa}$ for three days and placed to germinate in higher than $-0.75 \mathrm{MPa}$ saline potentials had a lower final germination percentage than the control sample. Thus, conditioning at -1.5 $\mathrm{MPa}$ water potential for three days damaged the germination of E. urophylla seeds (Figure 2D).

Among tested combinations of conditioning potential, germination saline potentials and time (Table 1), it was observed that conditioned seeds at -1.0 MPa for three days enabled the highest germination profits when submitted to more severe salt stress (-1.0 MPa). As well as enabling a higher final germination percentage, during evaluations it was visually perceptible that conditioning also allowed a better development of seedlings.

For E. urophylla $x$ E. grandis hybrid, the interaction between factor (conditioning $\mathrm{x}$ time $\mathrm{x}$ stress) and additional factors was significant to germination. There was also an interaction between conditioning potentials and stress levels, and between conditioning duration and stress levels. It was possible to observe a progressive germination reduction, as the potential of germination substrate reduced (Figure 1). Thus, it was possible to observe the influence of osmotic conditioning since the less negative potentials to the most negative ones. 
For -0.5 and $-0.75 \mathrm{MPa}$ stresses, conditioning at $-1.5 \mathrm{MPa}$ for three days raised germination from $77 \%$ to $90 \%$ and from $35 \%$ to $63 \%$, respectively (Figures $2 \mathrm{~F}$ and $2 \mathrm{G}$ ). Under the most severe salt stress, the -1.0 MPa one, seed germination was raised from $13 \%$ (control sample) to $28 \%$ after being conditioned for three days at -1.0 MPa (Figure 2H).
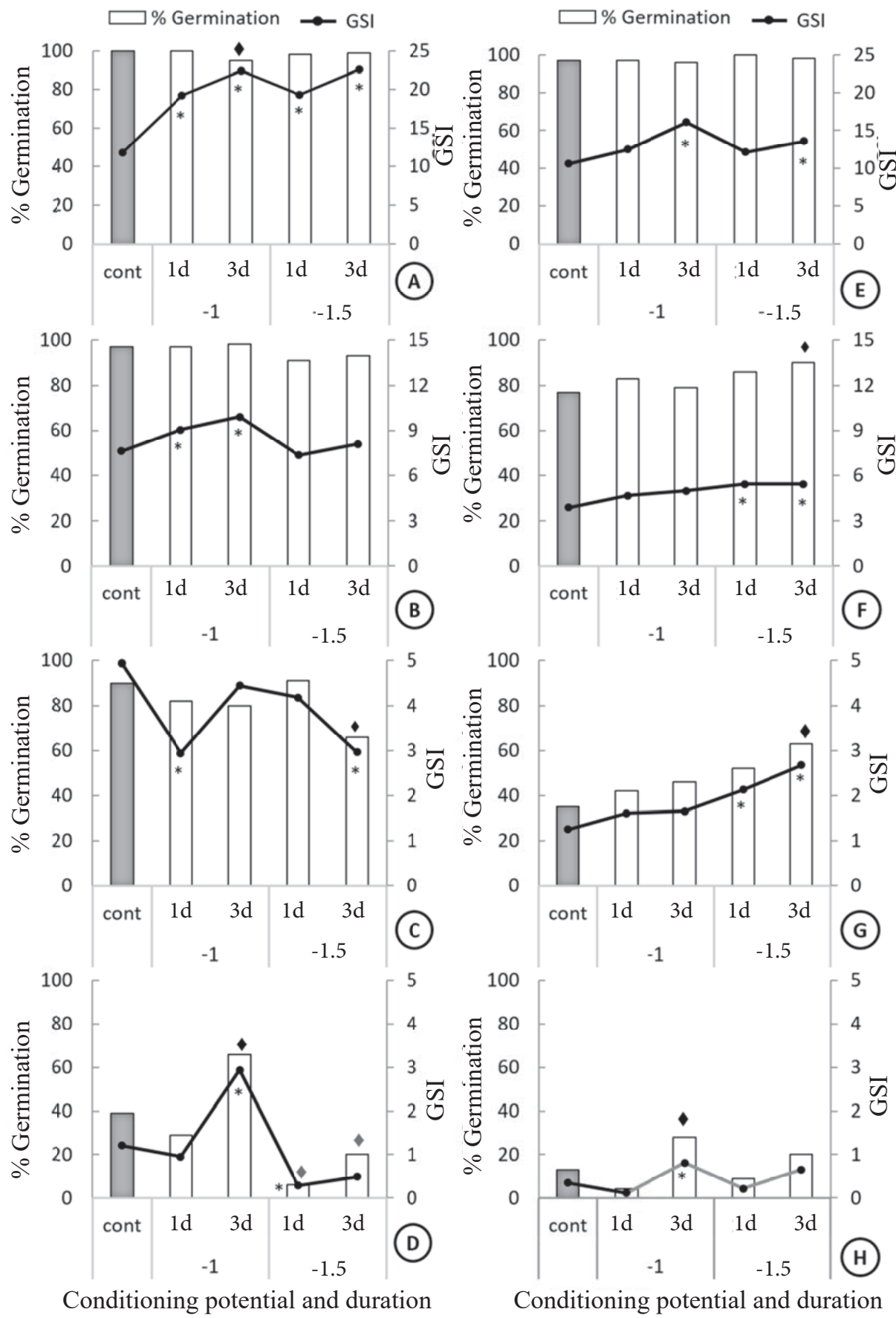

Figure 2. Statistical analysis based on the contrast between control sample treatment (cont) and the other priming treatments (-1.0 $\mathrm{MPa}$ or $-1.5 \mathrm{MPa}$ for 1 or 3 days) for Eucalyptus urophylla (left) and E. urophylla $x$ E. grandis (right). A and E refer to seeds placed to germinate in water dampened substrate; $\mathrm{B}$ and $\mathrm{F}$ substrate dampened with $\mathrm{NaCl}$ solution at $-0.5 \mathrm{MPa}$; $\mathrm{C}$ and $\mathrm{G}$ substrate dampened with -0.75 MPa solution and D and H substrate dampened with -1.0 MPa solution. * symbolizes treatments whose GSI statistically differed from the control sample treatment GSI. symbolizes treatment whose germination percentage was statistically different from the germination percentage of the control sample treatment. 
Table 1. Final germination percentage of Eucalyptus urophylla seeds for each combination of priming potential (-1.0 and -1.5 $\mathrm{MPa})$, priming duration ( 1 or 3 days) and stress level $(0,-0.5,-0.75$ and $-1.0 \mathrm{MPa})$.

\begin{tabular}{|c|c|c|c|c|c|c|c|c|}
\hline \multirow{3}{*}{ Conditioning } & \multicolumn{8}{|c|}{ Stress / time } \\
\hline & \multicolumn{2}{|c|}{0} & \multicolumn{2}{|c|}{-0.5} & \multicolumn{2}{|c|}{-0.75} & \multicolumn{2}{|c|}{-1.0} \\
\hline & $1 d$ & $3 d$ & $1 d$ & $3 d$ & $1 d$ & $3 d$ & $1 d$ & $3 d$ \\
\hline-1.0 & $100 \mathrm{Aa}$ & $95 \mathrm{Aa}$ & $97 \mathrm{Aa}$ & $98 \mathrm{Aa}$ & $82 \mathrm{Ba}$ & $80 \mathrm{Aa}$ & $29 \mathrm{Ab}$ & $66 \mathrm{Aa}$ \\
\hline-1.5 & $98 \mathrm{Aa}$ & $99 \mathrm{Aa}$ & $91 \mathrm{Aa}$ & $93 \mathrm{Aa}$ & $91 \mathrm{Aa}$ & $66 \mathrm{Bb}$ & $6 \mathrm{Bb}$ & $20 \mathrm{Ba}$ \\
\hline
\end{tabular}

Different letters (capital letters) in the columns represent the statistical difference among conditionings in each condition of time and stress.

Different letters (lowercase letters) in the columns represent the statistical difference among conditionings in each condition of time and stress. Averages were compared by Scott-Knott test at $5 \%$ probability.

Among the tested conditioning treatments, it was observed that seed response to conditioning potential and time was influenced by salt stress levels during germination. The conditioning potential of -1.5 MPa was more effective than -1.0 $\mathrm{MPa}$ to induce seed tolerance to germination under moderate salt stress (-0.75 MPa) (Table 2). As for conditioning duration, it was observed that maintaining seeds for three days in a PEG solution results in a higher final germination percentage than the treatment for just one day, when E. urophylla $x$ E. grandis seeds are submitted to -1.0 MPa salt stress (Table 2).

Table 2. Final germination percentage of Eucalyptus urophylla $x$ E. grandis seeds for each combination of priming potential and stress level, and for the priming duration and stress level combination.

\begin{tabular}{cccccr}
\hline & & \multicolumn{4}{c}{ Stress } \\
\cline { 2 - 6 } & & 0.0 & -0.5 & -0.75 & -1.0 \\
\hline \multirow{2}{*}{ Priming } & -1.0 & $97 \mathrm{Aa}$ & $81 \mathrm{Ab}$ & $44 \mathrm{Bc}$ & $16 \mathrm{Ad}$ \\
& -1.5 & $99 \mathrm{Aa}$ & $88 \mathrm{Ab}$ & $58 \mathrm{Ac}$ & $15 \mathrm{Ad}$ \\
\hline \multirow{2}{*}{ Duration (days) } & 1 & $98 \mathrm{Aa}$ & $85 \mathrm{Ab}$ & $47 \mathrm{Ac}$ & $6 \mathrm{Bd}$ \\
& 3 & $97 \mathrm{Aa}$ & $85 \mathrm{Ab}$ & $55 \mathrm{Ac}$ & $24 \mathrm{Ad}$ \\
\hline
\end{tabular}

Different letters (capital letters) in the columns represent the statistical difference, by Scott-Knott test at $5 \%$ probability for each variable (conditioning potentials and duration). Different letters (lowercase letters) in the columns represent the statistical difference, by Scott-Knott test at 5\% probability for each variable (conditioning potentials and duration)

Fredj et al. (2013), when studying five conditioning levels in coriander cultivars $\left(0,2,4,6\right.$ and 9 g. $\left.\mathrm{L}^{-1} \mathrm{NaCl}\right)$ for three duration periods (12, 24 and 36 hours), verified that the higher the duration, the lower the benefits of conditioning and that a conditioning saline solution in the 4 g. $\mathrm{L}^{-1}$ concentration provided the best germination results, decreasing significantly in higher concentrations. This demonstrates that an effective conditioning is highly dependent both on the osmotic potential of the solution and on the treatment duration, and that each species or cultivar responds to this conditioning in a different way. If on one hand low potentials of the conditioning solution or short periods may not provide all conditioning benefits, on the other hand high potentials, long duration or drying after conditioning may lead to overpriming, which causes damages to seeds, germination reduction and longevity (Reis et al., 2013).

Stree response is a dynamic process that depends on stress intensity and duration (Kosová et al., 2011). A less intense and shorter stressful event may be partially compensated by plant acclimatization, adaptation and repair. On the other hand, more intense and longer stressful events may cause irreversible damages, even leading to plant death (Kranner et al., 2010).

\section{Conclusions}

Salt stress reduced the germination percentage and speed of E. urophylla $x$ E. grandis and E. urophylla seeds.

The osmotic conditioning induced by PEG enabled an increase in the final germination speed and percentage under salt stress for both species.

The responses of E. grandis and E. urophylla seeds depend on conditioning potential, incubation period and stress conditions to which they are submitted.

\section{Acknowledgments}

To the National Council for Scientific and Technological Development (CNPq) and the Research Support Foundation of Minas Gerais State (FAPEMIG), for the financial support.

\section{References}

ASHRAF, M. Some important physiological selection criteria for salt tolerance in plants. Flora, v.199, n.5, p.361-376, 2004. http://dx.doi org/10.1078/0367-2530-00165

DUNN, G.M.; TAYLOR, D.W.; NESTER, M.R.; BEETSON, T.B Performance of twelve selected Australian tree species on a saline site in southeast Queensland. Forest Ecology and Management, v.70, n.1-3, p.255264, 1994. http://dx.doi.org/10.1016/0378-1127(94)90091-4 
FEIKEMA, P.M.; BAKER, T.G. Effect of soil salinity on growth of irrigated plantation Eucalyptus in south-eastern Australia. Agricultural Water Management, v.98, n.7, p.1180-1188, 2011. http://dx.doi.org/10.1016/j. agwat.2011.03.005

FREDJ, M.B.; ZHANI, K.; HANNACHI, C.; MEHWACHI, T. Effect of $\mathrm{NaCl}$ priming on seed germination of four coriander cultivars (Coriandrum sativum). EurAsian Journal of BioSciences, v.7, p.21-29, 2013. http://dx.doi. org/10.5053/ejobios.2013.7.0.3

GHOLAMI, M.; MOKHTARIAN, F.; BANINASAB, B. Seed halopriming improves the germination performance of black seed (Nigella sativa) under salinity stress conditions. Journal of Crop Science and Biotechnology, v.18, n.1, p.21-26, 2015. http://dx.doi.org/10.1007/s12892-014-0078-1

HARFOUCHE, A.; MEILAN, R.; ALTMAN, A. Molecular and physiological responses to abiotic stress in forest trees and their relevance to tree improvement. Tree Physiology, v.34, n.11, p.1181-1198, 2014. http://dx.doi. org/10.1093/treephys/tpu012

IBRAHIM, E.A. Seed priming to alleviate salinity stress in germinating seeds. Journal of Plant Physiology, v.192, n.15, p.38-46, 2015. http://dx.doi. org/10.1016/j.jplph.2015.12.011

JISHA, K.C.; VIJAYAKUMARI, K.; PUTHUR, JOS T. Seed priming for abiotic stress tolerance: an overview. Acta Physiologiae Plantarum, v.35, n.5, p.1381-1396, 2013. http://dx.doi.org/10.1007/s11738-012-1186-5

KOSOVÁ, K.; VÍTÁMVÁS, P.; PRÁŠIL, I.T.; RENAUT, J. Plant proteome changes under abiotic stress-contribution of proteomics studies to understanding plant stress response. Journal of Proteomics, v.74, n.8, p.13011322, 2011. http://dx.doi.org/10.1016/j.jprot.2011.02.006

KRANNER, I.; MINIBAYEVA, F.V.; BECKETT, R.P.; SEAL, C.E. What is stress? Concepts, definitions and applications in seed science. New Phytologist, v.188, n.3, p.655-673, 2010. http://dx.doi.org/10.1111/j.14698137.2010.03461.x

KUBALA, S.; WOJTYLA, Ł.; QUINET, M.; LECHOWSKA, K.; LUTTS, S.; GARNCZARSKA, M. Enhanced expression of the proline synthesis gene P5CSA in relation to seed osmopriming improvement of Brassica napus germination under salinity stress, Journal of Plant Physiology, v.183, n.1, p. 1-12, 2015. http://dx.doi.org/10.1016/j.jplph.2015.04.009
LARCHER, W. Ecofisiologia vegetal. São Carlos: Rima, 2000. 531p.

MARTINS, C.C.; PEREIRA, M.R.R.; LOPES, M.T.G. Germinação de sementes de eucalipto sob estresse hídrico e salino. Bioscience Journal, v.30, n.1, p.318-329, 2014. http://www.seer.ufu.br/index.php/biosciencejournal/ article/view/18058/14543

NIKNAM, S.R; McCOMB, J. Salt tolerance screening of selected Australian woody species - a review. Forest Ecology and Management, v.139, n.1, p.119, 2000. http://dx.doi.org/10.1016/S0378-1127(99)00334-5

PASTORI, G.M.; FOYER, C.H. Common components, networks, and pathways of cross-tolerance to stress. The central role of "redox" and abscisic acid-mediated controls. Plant Physiology, v.129, n.2, p.460-468, 2002. http:/ /dx.doi.org/10.1104/pp.011021

REIS， R.G.E.; SILVA， H.P.; NEVES， J.M.G.; GUIMARÃES， R.M. Physiological quality of osmoprimed gherkin seeds. Journal of Seed Science, v.35, n.3, p.368-373, 2013. http://dx.doi.org/10.1590/S231715372013000300014

SHABALA, S.; MUNNS, R. Salinity Stress: Physiological constraints and adaptive mechanisms. In: SHABALA, S. (ed.). Plant Stress Physiology. Oxford: United Kingdom \& USA, 2012. p.59-93.

SU, X.; CHU, Y.; LI, H.; HOU, Y.; ZHANG, B.; HUANG, Q.; HU Z.; HUANG, R.; TIAN, Y. Expression of multiple resistance genes enhances tolerance to environmental stressors in transgenic poplar (Populus $\times$ euramericana 'Guariento'). PLoS ONE, v.6, n.9, 2011. http://dx.doi.org/10.1371/journal. pone. 0024614

SUN, W.Q. Methods for the study of water relations under desiccation stress In: BLACK, M.; PRITCHARD, H.W. (ed.). Desiccation and survival in plants: Drying without dying. Wallingford: Cabi Publishing, UK, 2002. p.4792.

TAYLOR, A.G.; ALLEN, P.S.; BENNETT, M.A.; BRADFORD, K.J.; BURRIS, J.S.; MISRA, M.K. Seed enhancements. Seed Science Research, v.8, n.2, p.245-256, 1998. http://dx.doi.org/10.1017/S0960258500004141 